\title{
Preliminary Antifungal Study of Some Essential Oils of Three Medicinal Plants Against Fusarium Oxysporum f. sp. ciceris, and Aspergillus Niger
}

\author{
Farah Khameis Farag Teia ${ }^{1}$, Ahmed Osman ${ }^{2}$, Magda Abaker Osman ${ }^{1}$ \\ ${ }^{1}$ Department of Agro-technology, Medicinal and Aromatic Plants and Traditional Medicine Research Institute, National Centre for Research, \\ Khartoum, Sudan \\ ${ }^{2}$ Department of Microbiology, Medicinal and Aromatic Plants and Traditional Medicine Research Institute, National Centre for Research, \\ Khartoum, Sudan
}

Email address:

farfor157@gmail.com (F. K. F. Teia)

To cite this article:

Farah Khameis Farag Teia, Ahmed Osman, Magda Abaker Osman. Preliminary Antifungal Study of Some Essential Oils of Three Medicinal Plants Against Fusarium Oxysporum f. sp. ciceris, and Aspergillus Niger. International Journal of Bioorganic Chemistry.

Vol. 3, No. 1, 2018, pp. 1-5. doi: 10.11648/j.ijbc.20180301.11

Received: August 17,2017; Accepted: November 9, 2017; Published: January 9, 2018

\begin{abstract}
The aim of this study is to investigate preliminary antifungal activity of three essential oils by disc diffusion method, the essential oils of three plants used in traditional Sudanese medicine namely Mentha spicata (Lamiaceae), Cymbopogon schoenanthus L. (Poaceae), and Citrus reticulata (Rutaceae), was evaluated for their ability to inhibit the growth of selected phytopathogenic fungi Fusarium oxysporum f. sp. ciceris (causing wilt in chick pea) and the standard fungi Aspergillus niger was used for comparison. Essential oils were extracted by hydrodistilation using Clevenger apparatus. The experiment was carried out using disc diffusion method in different concentrations of essential oil on PDA culture at $25^{\circ} \mathrm{C}$. The result showed essential oil of studied plants in all concentrations had completely inhibited growth for tested fungi.
\end{abstract}

Keywords: Antifungal, Essential Oil, Disc Diffusion, Phytopathogen

\section{Introduction}

Aromatic plants have great importance for food, cosmetics and pharmaceutical industries due to its essential oil content. The essential oils are aromatic substances which are obtained from various plant parts by steam or hydro distillation. They have been used since ancient times and many of which exhibit antibacterial [1], antifungal [2] [3] and antiviral [4] activity. Despite many of essential were substituted by synthetic ones, the demand for natural products is increasing. Pesticide residues in agricultural products and the incidence of resistance in plant pathogens against chemical pesticides demonstrates, the need for non-chemical methods including natural metabolites. Application of natural compounds on phytopathogens almost returns to the time the plant disease were ascribed. However, the search for natural products with antimicrobial activity was accelerated from a few past decades [5].

For example, monoterpene limonene has shown to possess deterrent and insecticide properties and corvine is used as a sprout inhibitor [6] [7]. Essential oils are complex and highly variable mixtures of constituents that belong to two groups: terpenoids and aromatic compounds. Hydrocarbons are almost always present in monoterpenes [8].

Essential oils are valuable natural products used as raw materials in many fields, including perfumes, cosmetics, aromatherapy, phytotherapy, spices and nutrition. Aromatherapy is the therapeutic use of fragrances or at least mere volatiles to cure, mitigate or prevent diseases, infections and indispositions by means of inhalation. [9].

The genus Mentha includes 25-30 species that grow in the temperate regions of Eurasia, Australia and South Africa. The mint species have a great importance, both medicinal and commercial. Indeed, leaves, flowers and stems of Mentha spp. are frequently used in herbal teas or as additives in commercial spice mixtures for many foods to offer aroma and flavour. In addition, Mentha spp. has been used as a folk remedy for treatment of nausea, bronchitis, flatulence, 
anorexia, ulcerative colitis, and liver complaints due to its anti-inflammatory, carminative, antiemetic, diaphoretic, antispasmodic, analgesic, stimulant, emmenagogue, and anticatharrhal activities [10].

As a medicinal part, the leaf or the plant, and the drug are used officinal in many national pharmacopoeia. Owing to their complex chemical composition, the preparations made of Mentha species, show anti-inflammatory, antimicrobial, spasmodic, carminative, antioxidant properties. In the traditional and conventional medicine these preparations are used for better digestion, they improve the secretion of the gall. In addition, the essential oils isolated from Mentha species, are used externally, in the preparations which alleviate pains in the muscles and in the treatments against neuralgia, but the largest quantities are used in cosmetic and food industry for production of different sweets and beverages [11] [12].

Cymbopogon is an important genus of the Poaceae family is widely distributed in the tropical and subtropical regions of Africa, Asia and America. Comprised of 144 species, this genus is famous for its high content of essential oils which have been used for cosmetics, pharmaceuticals, and perfumery applications [13] [14]. Half bar, the common name of Cymbopogon schoenanthus (L.) spreng, is a common weed grows in southern Egypt and Northern parts of Sudan [15].

Citrus reticulata, comon name is mandarin is an evergreen tree growing up to $4.5 \mathrm{~m}$ by $3 \mathrm{~m}$. this plant possess antioxidant effect [16] [17] and antimicrobial [17]. It is a source of natural compounds such as citruscridone [18] citriolide-A [19] isolimonexic acid methyl ether, in addition to the previously isolated limonin, deacetylnomilin, obacunone and ichangin, the marginal antimalarial activity of isolimonexic acid methyl ether is reported [20]. It has phenolic [17] and flavonoids among its components [21].

Fusarium oxysporum has been reported as soil born and seed borne pathogens containing more than 150 form species infected specific host [22] [23] [24]. Fusarium oxysporum $f$. $s p$. ciceris is an important fungal pathogen causing wilt in chickpea (Cicer arietinum L.) in many countries, and their losses ranging from $10-40 \%$ worldwide [25] [26] and is capable of causing $100 \%$ yield loss. In Sudan chickpea is one of the important legume crops and it is grown under irrigation system as a winter crop.

The aim of this study is to investigate preliminary antifungal activity of three essential oils by disc diffusion method.

\section{Methods}

\subsection{Plant Materials}

Plants were collected from different area, chamel's hay and mint from the experimental farm of our Agrotechnology Department, Shambat. And mandarin plant was bought from local market, Khartoum.

The plant names, and the plant parts used for the study are shown in (Table 2).

\subsection{Method of Extraction}

Plants Essential oils were extracted by Hydrodistillation using Clevenger Apparatus for 3 hours and dried using anhydrous sodium sulphate.

\subsection{Preparation of Essential Oils for Bioassay}

To prepare the stock solutions of essential oil, the essential oil was dissolved in methanol. Sample with known weights were further diluted with $10 \%$ of the methanol solvents used to prepare test samples, where the final concentration of the solvent was $0.625 \%(6.25 \mu \mathrm{l} / \mathrm{ml})$.

\subsection{Preparation of Fungal Suspension}

F. oxysporum f. sp. ciceris obtained from Microbial Type Culture Collection, Central lab of Plant Pathology, Plant Protection Directorate. This fungus was grown on Sabouraud dextrose agar plate at $28^{\circ} \mathrm{C}$ and maintained with periodic sub-culturing at $4^{\circ} \mathrm{C}$. The fungal cultures of $F$. oxysporum $\mathrm{f}$. sp. ciceris, were maintained on Sabouraud dextrose agar (SDA), incubated at $25^{\circ} \mathrm{C}$ for 4 days. The fungal growth was harvested and washed with sterile normal saline and finally suspension in $100 \mathrm{ml}$ of sterile normal saline, to produce a suspension containing about $10^{8}$ to $10^{9} \mathrm{CFU} / \mathrm{ml}$. The suspension was stored in the refrigerator at $4{ }^{\circ} \mathrm{C}$ till used. While the suspension culture of the standard fungi Aspergillus niger was obtained from Microbiology and Parasitology Department (Medicinal and Aromatic Plants and Traditional Medicine Research Institute (MAPTMRI), Khartoum, Sudan.).

\subsection{Biological Assay of Antifungal Activities}

The determination of the antifungal effect of the essential oil was tested according to the disc diffusion method [27] [28]. Fungal suspension was diluted with sterile physiological solution to $10^{8} \mathrm{cfu} / \mathrm{ml}$ (turbidity $=$ McFarland standard 0.5). Sterilized filter paper discs (Whatman No. 1, 6 $\mathrm{mm}$ in diameter) were placed on the surface of the SDA and soaked with $20 \mu \mathrm{l}$ of a solution of each plant extracts. The inoculated plates were incubated at $37{ }^{\circ} \mathrm{C}$ for $24 \mathrm{~h}$ in the inverted position and plates were used in triplicate for each treatment. The diameters $(\mathrm{mm})$ of the inhibition zones were measured.

\section{Results and Discussion}

The mean diameter of inhibition zones produced by the candidate essential oils against the studied fungi is presented as screening antifungal activity $(100 \mu \mathrm{l} / \mathrm{ml})$. The results were expressed in terms of the diameter of the inhibition zone according to Mukhtar and Ghori [29]. The result (in Table 1) showed that the candidate essential oil was more active against the $A$. niger (the inhibition zones ranging between (21-25 mm)), and ranging (15-19 mm) for F. oxysporum f. sp. ciceris. The Camel's hay essential oil was more active 
against both of them (A. niger. $25 \mathrm{~mm} ; F$. oxysporum $\mathrm{f}$. sp. ciceris, $19 \mathrm{~mm})$, the essential oils of mandarin and mint were more active against $A$. niger, $(21 \mathrm{~mm})$ while it was active against $F$. oxysporum $\mathrm{f}$. sp. ciceris, $(15 \mathrm{~mm})$.

The inhibitory concentration of plants essential oil against fungal strains varied from plant extract to another. Moreover, the mean diameter of inhibition zones value of the same plant essential oil has changed according to the test organism (Table 2). The highest inhibition zone dimeter value, (27 mm), was obtained by camel's hay against Aspergillus niger. However, the result showed that the essential oil of studied plants in all concentrations had shown growth inhibition activity against $F$. oxysporum $\mathrm{f}$. sp. ciceris.

The essential oil concentrations that considered to be more active on $F$. oxysporum f. sp. ciceris was $(100 / 50 / 25 \mu \mathrm{l} / \mathrm{ml})$ of camel's hay, $(50 / 25 \mu \mathrm{l} / \mathrm{ml})$ of mint, and $(50 / 25 / 12.5 \mu \mathrm{l} / \mathrm{ml})$ of mandarin. In the other hand the active concentrations against $A$. niger, was $(100 / 50 / 25 / 12.5 \mu \mathrm{l} / \mathrm{ml})$ in the camel's hay, and only one concentration $(100 \mu \mathrm{l} / \mathrm{ml})$ in mint and mandarin. The lowest concentration showed activity $(6.25$ $\mu \mathrm{l} / \mathrm{ml}$ ) found in camel's hay against $A$. niger, $(17 \mathrm{~mm})$, but in mint and mandarin the growth inhibition zone was $(16 \mathrm{~mm})$ on F. oxysporum f. sp. ciceris.

Recently the search for natural plant products with antimicrobial activity has been accelerated due to the appearance of chemical pesticides residues and the development of pesticides resistant. Thus the search for nonchemical methods, including plant for treatment of phytopathogens has gain revival interest.

However, it is difficult to manage fusarium wilt through application of chemicals because of the pathogen persists in soil as well as on seed and each form species has many races [23] [24] [25] [30].

There is a good evidence in the literature that the plant extract and essentials of some families possess moderate to good antifungal activates, among them is Lamiaceae family [5], Poacea [31]. The studied plants were used for the first time to inhibit growth of $F$. oxysporum $\mathrm{f}$. sp. ciceris.

This result of the antifungal screening was similar to the previous research of El-Assiuty et al. [5] who reported that nhexane extract of $C$. schoenanthus inhibited the growth of Fusarium verticillioides and Aspergillus flavus. Their results were comparable to our findings found of Camel's hay essential oil against $\mathrm{F}$. oxysporum $\mathrm{f}$. sp. ciceris, and $A$. niger.

The essential oil of mint had ability to inhibit growth of $F$. oxysporum f. sp. radices - cucumerinum [5]. The essential oil of Citrus reticulata had capacity to inhibit the production and germination of the spores of fungi e. g. Fusaruim spp. [32] [33].

The result of our MIC study showed that mandarin essential oils was the most active against $F$. oxysporum f. sp. ciceris up to $12.5 \mu \mathrm{l} / \mathrm{ml}$ while both mint and Camel's hay essential oils were more active at $25 \mu \mathrm{l} / \mathrm{ml}$ (Table 2). The result of the inhibitory activity of the studied essential oils against both fungi depended on concentration. This result was in line with the result of Simin, et al. [5] who reported antifungal activity of mint essential oil on Fusarium oxysporum $f$. sp. radicis-cucumerinum, that the effect of growth inhibitory of plant essential oils depend on the amount of essential oil and the incubation time. And also the effects depend on species of fungi [34].

Table 1. Antifungal activity of essential oils $(\mu \mathrm{l} / \mathrm{ml})$ of selected medicinal plants against tested fungi.

\begin{tabular}{|c|c|c|c|c|}
\hline \multirow{2}{*}{ Family/Botanical Name/Vernacular name/Common name } & \multirow{2}{*}{ Part used } & \multirow{2}{*}{ Concentration $\mu \mathrm{l} / \mathrm{ml}$} & \multicolumn{2}{|l|}{ DZ (mm) } \\
\hline & & & F. oxysporum f. sp. cicer & A. niger \\
\hline Lamiaceae, Mentha spicata. Nanaa, Mint. & Leaves & 100 & 15 & 21 \\
\hline Poaceae, Cympobogon schouansus. Mahareib, Hamarib. Chamel's hay & Leaves & 100 & 19 & 25 \\
\hline Rutaceae Citrus reticulata Mandarin & Fruit peels & 100 & 15 & 21 \\
\hline
\end{tabular}

Table 2. Antifungal activity of essential oils at different concentrations $(50-6.25 \mu \mathrm{l} / \mathrm{ml})$.

\begin{tabular}{|c|c|c|c|}
\hline \multirow{2}{*}{ Family/Botanical Name/Vernacular name/Common name } & \multirow{2}{*}{ Concentration $\mu \mathrm{l} / \mathrm{ml}$} & \multicolumn{2}{|l|}{ Zone of inhibition (mm) } \\
\hline & & F. oxysporum f. sp. cicer & A. niger \\
\hline \multirow{4}{*}{ Lamiaceae, Mentha spicata. Nanaa, Mint } & 50 & 26 & 18 \\
\hline & 25 & 26 & 18 \\
\hline & 12.5 & 17 & 16 \\
\hline & 6.25 & 16 & 13 \\
\hline \multirow{4}{*}{ Poaceae, Cympobogon schouansus. Mahareib, Hamarib. Camel's hay } & 50 & 20 & 27 \\
\hline & 25 & 20 & 21 \\
\hline & 12.5 & 15 & 21 \\
\hline & 6.25 & 11 & 17 \\
\hline \multirow{4}{*}{ Rutaceae Citrus reticulata Mandarin } & 50 & 23 & 13 \\
\hline & 25 & 22 & 11 \\
\hline & 12.5 & 23 & 11 \\
\hline & 6.25 & 16 & 10 \\
\hline
\end{tabular}

\section{Conclusion}

It seems that the inhibitory activity of the essential oil of the three plant species was concentration dependant which showed a promising result to be promoted as antifungal candidate for plant disease management. The results indicated that the essential oils of studied plants had biological activity against $F$. oxysporum f. sp. ciceris, and Aspergillus niger, which may explain the traditional uses of 
the oils against plant fungal diseases, and that mean the essential oil of studied plant had a potential to be applied as antifungal agent. So more in vitro studies to comparison standard fungicide with this result, and more fields' experiments and investigation should be carried out to verify that result in vitro test and to determine the applicable dose, and also to develop a new and safe antifungal agent as a natural fungicides.

\section{Acknowledgements}

The authors thank to all Staff of Plant Pathology Department (Plant Protection Directorate), Ministry of Federal Agriculture, Microbiology and Parasitology, Phytochemistry Department (Medicinal and Aromatic Plants and Traditional Medicine Research Institute, NCR. Khartoum. Sudan).

\section{Conflicts of Interest}

The authors declare no conflict of interest.

\section{References}

[1] Ozcan, M. M. L., O. Sagdic and Ozkan, G. (2006). Inhibitory effects of spice essential oils on the growth of Bacillus species J. Med. Food, 9: 418-421.

[2] Chee, H. Y., and Lee, M. H. (2007). Antifungal activity of clove oil and its volatile vapour against dermatophytic fungi. Mycology, 35: 241-243.

[3] Andrea Bernardos., Teresa Marina., Petr Žáček., Édgar PérezEsteve., Ramón Martínez-Mañez., Miloslav Lhotka., Lenka Kouřimská., Josef Pulkrábek and Pavel Klouček. (2015). Antifungal effect of essential oil components against Aspergillus nigerwhen loaded into silica mesoporous supports. Journal of the Science of Food and Agriculture, 95 (14): 2824-2831.

[4] Khan, M. T., A. Ather, K. D., Thompson and Gambari, R. (2005). Extracts and molecules from medicinal plants against Herpes simplex viruses. Antivir. Rev., 67: 107-19.

[5] Simin, N., Seyyed Alireza Esmaeilzadeh Hosseini, Abolfzl Sarpeleh, Mahmoud SoflaeiShahrbabak and Yeganeh SoflaeiShahrbabak (2011). Antifungal Activity of Spearmint (Mentha Spicata L.) Essential Oil on Fusarium oxysporum $f$. sp. radicis-cucumerinum the Causal Agent of Stem and Crown Rot of Greenhouse Cucumber in Yazd, Iran. IPCBEE vol. 15: 54.

[6] Ibrahim, A. M., Kainulainen, P., Aflatuni, A., Tiilikkala, K., Holopainen, J. (2001). Insecticidal, repellent, antimicrobial activity and phytotoxicity of essential oils: With special reference to limonene and its suitability for control of insect pests. Agricultural and Food Science in Finland, 10: 243-59.

[7] Aflatuni, A. (2003). The use of plant origin substances against Galerucella sagitaria. Proceedings of the Nordic Association of Agricultural Scientists 22nd Congress "Nordic Agriculture in Global. Perspective", Turku, Finland.

[8] Bruneton, J. (1995). Pharmacognosy, Phytochemistry, Medicinal Plants. Lavoisier Publ Londres, New York, Paris.
PP: 405-66.

[9] Lahlou, M. (2004). Essential oils and fragrance compounds: bioactivity and mechanisms of action. Flavour and Fragrance Journal, 19: 159-165.

[10] Hadjlaoui, H., Najla, T., Emira, N., Mejdi, S., Hanen, F., Riadh, K., Amina, B. (2009). World J. Biotechnol. Microbiol. $25,2227-2238$.

[11] PDR for Herbal Medicines, 2004. Third Edition, Thomson PDR at Montvale, 283-284.

[12] Mimica-Dukić, N. and Božin, B. (2008). Mentha L. Species (Lamiaceae) as promising sources of bioactive secondary metabolites, Curr. Pharm. Design. 14: 3141-3150.

[13] Khanuja, S. P. S., Shasany, A. K., Pawar, A., Lal, R. K., Darokar, M. P., Naqvi, A. A., Rajkumar, S., Sundaresan, V., Lal, N., Kumar, S. (2005). Essential oil constituents and RAPD markers to establish species relationship in Cymbopogon Spreng. (Poaceae). Biochem. Syst. Ecol., 33: 171-186.

[14] Noudogbessi, J. P., Alitonou, G. A., Djenontin, T. and Avlessi, F. (2013). Chemical Compositions and Physico-chemical Properties of Three Varieties Essential oils of Cymbopogon giganteus Growing to the Spontaneous State in Benin. Orient. J. Chem., 29 (1): 59-67.

[15] Boulos, L. (1999). In: Flora of Egypt, vol. 1. Al Hadara Publishing, Cairo, Egypt, pp. 291-301.

[16] Xiangtao, C., Ke, Y., Hualiang, L. (2010). Phenolic contents and antioxidant activities in ethanol extracts of Citrus reticulata Blanco cv. Ougan fruit. Journal: Food, Agriculture and Environment (JFAE), 8 (2): 150-155.

[17] Feás, X., Estevinho, L. M., Carmen, S., Pilar, V., Sainz, M. J., Vázquez-Tato M. P. (2013). Triacylglyceride, antioxidant and antimicrobial features of Virgin Camellia oleifera, $C$. reticulata and C. sasanqua Oils. Molecules, 18 (4): 4573-4587.

[18] Phetkul, U., Nutthakran, W., Wilawan, M., Souwalak, P., Carroll, A. R., (2013). New acridone from the wood of Citrus reticulata Blanco. Natural Product Research, 27 (20): 19221926.

[19] Jun, L., Teng, X., Yun-Hai, L., Shi-Zhong, W. (2012). A new limonoid from the seeds of Citrus reticulata Blanco. Natural Product Research, 26 (8): 756-761.

[20] Khalil AT, Galal TM, El Sayed AK, (2003). Limonoids from Citrus reticulata. Zeit. Naturforsch C 2003; 58 (3): 165- 170.

[21] Sun Y, Jianhua W, Shubo G, Zhengbo L, Yujie Z, Xiaoxia Z, (2010). Simultaneous determination of flavonoids in different parts of Citrus reticulata 'Chachi' fruit by high performance liquid chromatography-photodiode array detection. Molecules, 15 (8): 5378-5388.

[22] Baayen R. P., O'donnell K., Bonants P. J. M., Cigelnik E., Kroon Laurens P. N. M., Roebroeck E. J. A. and Waalwijk C. (2000) Gene Genealogies and AFLP Analyses in the Fusarium oxysporum Complex Identify Monophyletic and Nonmonophyletic Formae Speciales Causing Wilt and Rot Disease. Phytopathology. 90: 891-900.

[23] Haware MP, Nene YL, Rajeshwari R (1978) Eradication of Fusarium oxysporum f. sp. ciceri transmitted in chickpea seed. Phytopathology 68: 1364-1367. 
[24] Haware MP, Nene YL, Natrajan M (1986) Survival of Fusarium oxysporum f. sp. ciceri in soil in the absence of chickpea. National seminar on management of soil-borne diseases of crop plants (abstract). TNAU Coimbatore, 8-10 January.

[25] Nene, Y. L., V. K. Sheila and S. B. Sharma. (1984). A world list of chickpea (Cicer arietinum L.) and pigeonpea (Cajanus cajan (L.) Millsp.) pathogens. ICRISAT Pulse Pathology Progress Report 32, pp. 19.

[26] Kaiser, W. J., A. R. Alcalá-Jiménez, A. Hervas-Vargas, J. L. Trapero-Casas and R. M. Jiménez-Díaz. (1994). Screening of wild Cicer species for resistance to race 0 and 5 of Fusarium oxysporum f. sp. ciceris. Plant Disease, 78: 962-967.

[27] National Committee for Clinical Laboratory Stan-dards (NCCLS 1999). Performance standards for antimicrobial susceptibility testing; ninth infor-mational supplement. Wayne, Pensilvaniadocu-ment M100-S9, Vol. 19.

[28] Duru, M. E., Cakir, A., Kordali, S., Zengin, H., Harmandar, M., Izumi, S., Hirata, T. (2003). Chemical composition and Antifungal properties of Essential Oil of three Pistacia species. Fitoterapia, 74: 170-176.

[29] Mukhtar, S. and Ghori, I. (2012). Antibacterial Activity of Aqueous and Ethanolic Extracts of Garlic, Cinnamon and Turmeric against Escherichia coli ATCC 25922 And Bacillus subtilis Dsm 3256. International Journal of Applied Biology and Pharmaceutical Technology, 3 (2): 131-136.

[30] Jalali BL, Chand H (1992) Chickpea wilt. In: Singh US, Mukhopadhayay AN, Kumar J, Chaube HS (eds) Plant diseases of international importance, vol 1. Diseases of cereals and pulses. Prentice Hall, Englewood Cliffs, N. Y., pp 429 444.

[31] El-Assiuty, E. M., Bekheet, F. M., Fahmy, Z. M., Ismael, A. M. and El-Alfy, T. S. M. (2006). Potentiality of some isolated compounds from Halfa barr Cymbopogon proximus Stapf. Against the toxigenic fungi Fusarium verticilliodes and Aspergillus flavus. Egypt. J. Phytopathol., 342: 75-84.

[32] Chutia, M., P. Deka, Bhuyan, M. G. Pathak, T. C. Sarma and P. Boruah (2009). Antifungal activity and chemical composition of Citrus reticulata Blanco essential oil against phytopathogens from North East India. LWT - Food Science and Technology. 42: 777-780).

[33] Zohra, H. F., Rachida, A., Malika, M., Benali, S., Smir, A. A. and Bourai, M. (2015). Chemical Composition and Antifungal Activity of Essential Oils of Algerian Citrus. African Journal of Biotechnology, 14 (12): 1048-1055.

[34] Amini M, Safaie N, Salmani MJ, And Shams-Bakhsh M. (2012). Antifungal activity of three medicinal plant essential oils against some phytopathogenic fungi. Trakia J Sci, 10: 1-8. 